UDK: 28-428:637.5:[636/639:637.513.1“15/20“

Izvorni naučni rad Primljeno: 12. 9. 2019.

Prihvaćeno za štampu: 13. 1. 2020.

dr. sci. Hakija Kanurić, docent

Univerzitet u Bihaću

Islamski pedagoški fakultet

E-mail:hakijak@hotmail.com

\title{
HALAL MESO I SAVREMENI NAČIN KLANJA ŽIVOTINJA
}

\section{Sažetak}

Meso nekih životinja apsolutno je zabranjeno konzumirati dok je meso drugih dozvoljeno uz određene uvjete. Životinje koje žive isključivo u vodi dozvoljene su i bez posebnog klanja, za razliku od kopnenih životinja čije meso će biti dozvoljeno samo ako se na poseban način zakolju. Pritom je nužno da se ispune određeni uvjeti vezani za samu životinju, osobu koja kolje, način na koji to radi i pribor koji koristi. Ovaj rad bavi se analizom tih uvjeta, uz osvrt na načine ubijanja životinja u savremenim klaonicama. Komparacijom četiri poznata mezheba ekspliciraju se stavovi učenjaka o vrstama životinja čije meso je zabranjeno konzumirati. Pri tome se ukazuje na pitanja u kojima su učenjaci zauzeli jedinstven stav i pitanja u kojima su se razišli, kao $i$ argumente na koje se pozivaju i koje mišljenje se preferira.

Ključne riječi: islam, hrana, meso, životinje, klaonice, halal, haram.

\section{Uvod}

Svevišnji Allah posebnu je čast ukazao čovjeku učinivši da mu sve na Zemlji služi. U tom smislu Uzvišeni Allah kaže: „On je za vas sve što postoji na Zemlji stvorio.“ (El-Bekara, 29) Tako su i životinje potčinjene čovjeku. Pored brojnih koristi koje ljudima donose one su i važan izvor ljudske hrane. Ljudska hrana klasificira se po različitim osnovama, a islamski pravnici imaju za cilj ukazati na vrste hrane $\mathrm{s}$ aspekta Šerijata i pojasniti šta je dozvoljeno, pokuđeno i zabranjeno, te su po toj osnovi podijelili hranu u dvije osnovne kategorije: 
- Prva je hrana koja nije životinjskog porijekla, poput bilja, žitarica, voća, povrća, gljiva, minerala i sl. Sva ta hrana dozvoljena je, izuzev one u kojoj se nađe neki od općih uzroka zabrane, a to su štetnost, nečistoća, ogavnost, opojno ili narkotično dejstvo. ${ }^{1}$

- Druga kategorija je hrana životinjskog porijekla. Životinje se dijele na vodene i kopnene. U svakoj od tih vrsta ima životinja čije je meso dozvoljeno konzumirati i drugih, čije je meso zabranjeno. Životinje čije je meso dozvoljeno dijele se na one čija je dozvola uvjetovana propisnim klanjem i one koje su dozvoljene i bez klanja. U nastavku će biti više riječi o tome, kao i uvjetima koji se moraju ispuniti da bi klanje životinja bilo u skladu s islamskim normama, te metodama klanja životinja u savremenim klaonicama.

\section{Vodene životinje}

To su životinje koje žive isključivo u vodi, bila ona slana ili slatka, kao što su vode okeana, mora, rijeka, jezera, močvara i sl. Prema učenjacima hanefijske pravne škole, sve vodene životinje su zabranjene izuzev riba. Također su zabranjene i ribe koje same uginu, tj. ribe čija smrt nije uzrokovana vanjskim faktorom. Ribe koje budu ubijene $\mathrm{u}$ vodi, poznatim, vanjskim uzrokom, dozvoljene su i nema razlike između njih i riba koje budu ulovljene mrežama, te uginu nakon što se izvade iz vode. ${ }^{2}$

Druge pravne škole, mimo hanefijske, stanovišta su da su sve vodene životinje dozvoljene jesti, čak i uginule ribe koje plutaju po površini vode, a tako i vodozemci koji provode dug period na kopnu, kao što su krokodili, morske kornjače, rakovi i sl. Ipak, među onima koji zastupaju ovo mišljenje postoje određena razilaženja. Tako, naprimjer, hanbelijski pravnici smatraju da su vodozemci dozvoljeni ako se propisno zakolju, ali iz dozvole izuzimaju žabe, zmije i krokodile. Žabe

\footnotetext{
${ }^{1}$ Pogledati: Kanurić Hakija, Aditivi i emulgatori u hrani i piću, Zbornik radova br. 10, IPF-a u Bihaću, 2018.

${ }^{2}$ Vidjeti: Kasani, Bedaius-sanai', 5/36-37.
} 
su zabranjene, jer ih je zabranjeno ubijati, zmije zbog ogavnosti, a krokodili zbog toga što su mesojedi. ${ }^{3}$

Hanefijski učenjaci sve vodene životinje izuzev riba tretiraju ružnim i ogavnim, pa ih stoga obuhvata zabrana spomenuta u ajetu u kojem Svevišnji Allah, opisujući Svoga Poslanika, kaže: “...koji će im lijepa jela dozvoliti, a ružna im zabraniti..." (El-A'raf, 157). Što se tiče zabrane konzumiranja uginule ribe koja pluta po površini vode, kao argument navode predanje u kojem se kaže da je Poslanik, sallallahu alejhi ve sellem, rekao: "Jedite ono što vam more izbaci ili ostane iza njega kada se povuče, a nemojte jesti ono što u njemu ugine pa pluta po njegovoj površini." 4 Međutim, ovo predanje nije vjerodostojno, kao što nisu vjerodostojna ni druga predanja o tome. ${ }^{5}$ Kao dokaz o zabrani konzumiranja ribe koja uginula pluta po površini vode, navodi se i mogućnosti da bude pokvarena i štetna, jer se ne zna kada je i kako uginula.

Stavu većine učenjaka, da su sve životinje koje žive isključivo u vodi dozvoljene, u prilog ide ajet: "Vama se dopušta da u moru lovite i ulov jedete, da se njime vi i putnici koristite" (El-Maida, 96). U ovom ajetu Svevišnji Allah dozvolio je sve vodene životinje ne praveći razliku između onih koje se nazivaju ribama ili nekim drugim nazivom. Kada je Allahov Poslanik, sallallahu alejhi ve sellem, upitan o uzimanju abdestu morskom vodom, rekao je: "Njegova voda je čista, a ono što ugine u moru je dozvoljeno." "Hadis ukazuje na dozvolu svih morskih životinja, svejedno da li su one iz mora bile uzete žive ili mrtve, da li su uginule i plutaju u vodi ili ne. Ovom ide u prilog i predaja Džabira, radijallahu anhu, u kojoj opisuje kako je skupina ashaba naišla na mrtvog kita kojeg je more izbacilo, te su danima jeli njegovo meso, a kada su kasnije o tome obavijestili Allahovog Poslanika, sallallahu alejhi ve sellem, on je rekao: “To je opskrba koju vam je Svevišnji Allah dao. Imate li tog mesa pa da i nas nahranite?" Zatim su poslali tog mesa

\footnotetext{
${ }^{3}$ Vidjeti: Dusuki, Hašijetud-Dusuki alaš-Šerhil-kebir, 2/115, Nevevi, El-Medžmu', 9/28, Ibnu Kudama, El-Mugni, 9/425 i El-Mevsuatul-fikhijjetul-kuvejtijje, 5/124-132.

${ }^{4}$ Ibnu Madža, br. 3247.

${ }^{5}$ Vidjeti: Ibnu Hazm, El-Muhalla, 6/63.

${ }^{6}$ Ahmed, br. 7233, Ebu Davud, br. 83, Tirmizi, br. 69 i drugi. Tirmizi kaže da je ovaj hadis hasen-sahih.
} 
Poslaniku, sallallahu alejhi ve sellem, pa je i on jeo. ${ }^{7}$ Ovaj je hadis dokaz da su i druge morske životinje, ne samo ribe, dozvoljene za jelo, i da su morske životinje koje uginu, bez propisanog šerijatskog klanja, također dozvoljene, i to u prirodnim okolnostima, ne samo u nuždi, jer je Allahov Poslanik, sallallahu alejhi ve sellem, konzumirao to meso nakon što je doneseno u Medinu.

Mišljenju hanefijskih učenjaka prema kojem su vodene životinje mimo riba ogavne oponira činjenica da ima mnogo ljudi zdrave prirode kojima to nije ružno niti ogavno. Mogućnost da uginula riba koja pluta po površini vode bude pokvarena i štetna nije dovoljan razlog da bude zabranjena, međutim, ako je pokvarenost i štetnost evidentna, u tom slučaju zabranjena je zbog štetnosti.

Što se tiče unutrice ribe, ako se radi o sitnim ribama, čista je i dozvoljena, prema mišljenju sve četiri mezheba, a ako se radi o krupnoj ribi, također je čista prema mišljenju učenjaka hanefijskog i hanbelijskog mezheba, kao i nekih malikija, nasuprot mišljenju šafijske pravne škole i većine malikija koji to tretiraju nečistim. ${ }^{8}$

\section{Kopnene životinje}

To su životinje koje žive na kopnu i ptice. Neke od tih životinja dozvoljene su konsenzusom islamskih učenjaka, a neupitnim konsenzusom zabranjena je samo jedna životinja, to je svinja, dok u pogledu ostalih zabranjenih životinja postoje veća ili manja razilaženja.

\section{Stoka}

Krave, deve, ovce i koze dozvoljene su konsenzusom islamskih učenjaka, koji je utemeljen na brojnim šerijatskim tekstovima, od kojih su riječi Svevišnjeg Allaha: "I stoku On za vas stvara; njome se od hladnoće štitite, a i drugih koristi imate, njome se najviše i hranite" (En-

\footnotetext{
${ }^{7}$ Muslim, br. 1935.

${ }^{8}$ Vidjeti: El-Merginani, El-Hidaje, 4/353, Ibnu Rušd, El-Bejanu vet-tahsil, 3/299, ErRemli, Nihajetul-muhtadži ila šerhil-minhadž, 8/150, Er-Ruhejbani, Metalibu ulinnuha fi šerhi Gajetil-muntaha, 6/329, i El-Mevsuatul-fikhijjetul-kuvejtijje, 5/128132.
} 
Nahl, 5). Stoka je naziv koji obuhvata četiri spomenute vrste: krave, deve, ovce i koze. ${ }^{9}$

\section{Divlje životinje koje se hrane biljem}

Meso divljih životinja koje nisu mesojedi i ne spadaju u gmizavce i glodare, kao što su srne i zebre, dozvoljeno je konsenzusom islamskih učenjaka. ${ }^{10}$

\section{Zečevi}

Zečevi su, također, dozvoljeni. To je stav većine islamskih učenjaka, a na to ukazuju vjerodostojna hadiska predanja, od kojih je kazivanje Enesa, radijallahu anhu, u kojem pripovijeda kako su jednom prilikom istjerali zeca iz njegove jazbine. Enes kazuje: "Ljudi su trčali za njim i umorili se, a ja sam ga stigao, uhvatio i odnio Ebu Talhi, koji ga je zaklao i poslao Allahovom Poslaniku, sallallahu alejhi ve sellem, njegove butove, pa je Poslanik, sallallahu alejhi ve sellem, to prihvatio." $" 11$

\section{Ptice}

Ptice koje nisu grabljivice niti lešinari, kao što su kokoši, patke, golubovi i sl., dozvoljeno je konzumirati. ${ }^{12}$

\section{Životinje koje je zabranjeno ubijati}

Nije dozvoljeno meso životinja koje je Zakonodavac zabranio da se ubijaju ili je naredio da se ubijaju i one koje su ogavne ljudima zdrave prirode. O životinjama koje je zabranjeno ubijati kazuje predanje Ibn Abbasa, radijallahu anhuma, u kojem kaže da je Vjerovjesnik,

\footnotetext{
${ }^{9}$ Vidjeti: El-Mevsuatul-fikhijjetul-kuvejtijje, 5/133.

${ }^{10}$ Vidjeti: ibid, 5/134.

${ }^{11}$ Buhari, br. 5489. Vidjeti: El-Mevsuatul-fikhijjetul-kuvejtijje, 5/133.

${ }^{12}$ Vidjeti: ibid, 5/137.
} 
sallallahu alejhi ve sellem, zabranio ubijanje četiri vrste životinja: mrava, pčelu, pupavca i sureda."13

\section{Konji}

Prema mišljenju većine učenjaka, konjsko meso dozvoljeno je konzumirati, dok je prema odabranom stavu hanefijskog mezheba, meso konja pokuđeno, a imam Ebu Hanifa, rahimehullah, smatra da je zabranjeno. Prvi stav bazira se na predanjima od kojih je hadis Džabira, radijallahu anhu, u kojem kaže: "Vjerovjesnik, sallallahu alejhi ve sellem, zabranio je meso magaraca, a dozvolio je meso konja."14 Argument koji ukazuje na pokuđenost ogleda se u oprečnosti stavova $u$ ovom pogledu, pa je stoga sigurnije izbjegavati takvu hranu. Isto tako, konji se koriste u borbi na Allahovom putu, a jedenjem njihovog mesa smanjuje se broj konja, pa je stoga pokuđeno konzumirati ga. Argument koji ukazuje na zabranu jeste ajet u kojem Uzvišeni Allah kaže: "I konje, i mazge, i magarce - da ih jašete, i kao ukras - a stvorit će i ono što ne znate" (En-Nahl, 8). U ajetu se govori o blagodatima koje je Allah podario ljudima u ovim životinjama, a to je da služe za jahanje i za ukras, dok jedenje nije spomenuto. To znači da njihovo meso nije jestivo, jer u protivnom i to bi bilo spomenuto, kao što je kazano o stoci: “...njome se najviše i hranite" (En-Nahl, 5). Ipak, odabrano je mišljenje da je konjsko meso dozvoljeno ili pokuđeno, jer argument koji ukazuje na zabranu uopćen je i nije toliko jasan, dok spomenuti hadis eksplicitno ukazuju na dozvolu. ${ }^{15}$

\section{Zvijeri}

U zabranjene životinje spadaju i zvijeri, a to su mesojedi koji očnjacima trgaju plijen, bilo da se radi o divljim životinjama poput vukova $\mathrm{i}$ lavova, ili pitome poput pasa i mački. Meso ovih životinja zabranjeno

\footnotetext{
${ }^{13}$ Ebu Davud, br. 5267 i Ibn Madža, br. 3224. Hadis je sahih po ocjeni šejha Albanija. Sured je ptica veća od vrapca, krupne glave i kljuna, hrani se sitnim insektima. Vidjeti: Ibrahim Mustafa, El-Mu'džemul-vesit, 1/512.

${ }^{14}$ Buhari, br. 5520 i Muslim, br. 1941.

15 Vidjeti: Kasani, Bedaius-sanai', 5/38-39, Dusuki, Hašijetud-Dusuki alaš-Šerhilkebir, 2/117, Er-Remli, Nihajetul-muhtadži ila šerhil-minhadž, 8/143, Ibnu Kudama, El-Mugni, 9/411 i El-Mevsuatul-fikhijjetul-kuvejtijje, 5/139.
} 
je konzumirati prema mišljenju većine islamskih učenjaka, nasuprot oficijelnom stavu malikijskih učenjaka, koji kažu da je pokuđeno konzumirati ove životinje, ali nije strogo zabranjeno. Jedan od argumenata koji ukazuje na zabranu jeste predanje Ebu Sa'lebe, radijallahu anhu, u kojem navodi da je Poslanik, sallallahu alejhi ve sellem, zabranio da se konzumira svaka zvijer koja ima očnjake. ${ }^{16}$ Neki koji smatraju da je zabranjeno konzumirati zvijeri iz zabrane su izuzeli hijene pozivajući se na predaje od ashaba koje na to ukazuju. ${ }^{17}$ Argumentirajući svoj stav, malikije se pozivaju na kur'anski ajet: "Reci: 'Ja ne vidim u ovome što mi se objavljuje da je ikome zabranjeno jesti ma šta drugo osim strvi, ili krvi koja istječe, ili svinjskog mesa - to je doista pogano - ili što je kao grijeh zaklano u nečije drugo, a ne $u$ Allahovo ime"" (El-En'am, 145). Meso zvijeri nije spomenuto u ovom ajetu, što znači da je dozvoljeno, a zabrana spomenuta u hadisima, prema njihovom mišljenju, ukazuje na pokuđenost, a ne na strogu zabranu kao što to shvata većina učenjaka. ${ }^{18}$

\section{Ptice grabljivice}

Ptice grabljivice, kao što su jastreb i orao, zabranjeno je jesti, prema mišljenju većine islamskih učenjaka, nasuprot zvaničnom mišljenju malikija, koji smatraju dozvoljenim meso ovih životinja, čak i ako se hrane nečistoćom. Jedan od dokaza koji ukazuje na zabranu jeste predanje Ibn Abbasa, radijallahu anhu, u kojem kazuje da je Poslanik, sallallahu alejhi ve sellem, zabranio da se jede svaka zvijer koja ima očnjake i svaka ptica koja ima kandže. ${ }^{19}$ Malikije se u ovom pitanju pozivaju na već spomenuti argument, tj. 145. ajet sure El-En'am, koji govori o zabranjenim životinjama među kojima nisu spomenute ptice grabljivice. ${ }^{20}$

\footnotetext{
${ }^{16}$ Buhari, br. 5530 i Muslim, br. 1932.

${ }^{17}$ Kao što je vjerodostojno predanje od Džabira, radijallahu anhu, koje bilježe Ahmed, br. 14165, Ebu Davud, br. 3801, Tirmizi, br. 851, Nesai, br. 4323 i Ibn Madža, br. 3236 .

${ }^{18}$ Vidjeti: Badži, El-Munteka šerhul-Muvetta, 3/131, Dusuki, Hašijetud-Dusuki alašŠerhil-kebir, 2/104 i El-Mevsuatul-fikhijjetul-kuvejtijje, 5/133.

${ }^{19}$ Muslim, br. 1934.

${ }^{20}$ Vidjeti: El-Mevsuatul-fikhijjetul-kuvejtijje, 5/135.
} 


\section{Ptice koje se pretežno hrane strvinom}

Ptice koje se pretežno hrane strvinom, kao što su lešinari i neke vrste gavranova, zabranjene su prema mišljenju većine islamskih učenjaka, jer je njihovo meso ogavno ljudima zdrave prirode, a prema mišljenju malikija također su dozvoljene. Na zabranu ukazuje predanje od Aiše, radijallahu anha, u kojem kaže da je Allahov Poslanik, sallallahu alejhi ve sellem, rekao: "Pet vrsta štetočina dozvoljeno je ubijati i u Haremu:

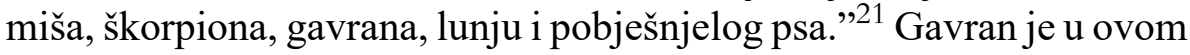
hadisu nazvan štetočinom, pa kako da bude dozvoljeno jesti ono što je Poslanik, sallallahu alejhi ve sellem, tako nazvao? Isto tako, gavrana koji je spomenut u hadisu dozvoljeno je ubiti, što znači da ga klanje neće učiniti dozvoljenim, jer ubijanje bi u tom slučaju značilo uništavanje imovine, a uništavati imovinu islam je zabranio. Malikije se u svemu tome pozivaju na ranije citiran ajet sure El-En'am u kojem se spominju zabranjene životinje, a ova vrsta ptica tu nije spomenuta. 22

\section{Magarci}

Meso magaraca zabranjeno je prema mišljenju većine islamskih učenjaka. Zabrana se temelji na predanju od Enesa, radijallahu anhu, u kojem navodi da je Poslanik, sallallahu alejhi ve sellem, na dan Hajbera naredio glasniku da ljudima obznani: "Allah i Njegov Poslanik zabranjuju vam meso magaraca, jer je ono nečisto!" Enes je rekao: "Pa su lonci prevrnuti iako se meso u njima kuhalo."23 Ibn Hazm navodi da devetorica ashaba prenose od Allahovog Poslanika, sallallahu alejhi ve sellem, vjerodostojna predanja o zabrani magarećeg mesa, te da su ta predanja, bez sumnje, vjerodostojna. ${ }^{24}$

\section{Gmizavci, glodari i insekti}

Ova kategorija dijeli se na dvije vrste: životinje koje imaju krvotok, kao što su zmije i miševi, i životinje koje nemaju krvotok, kao što su gušteri,

\footnotetext{
${ }^{21}$ Buhari, br. 3314 i Muslim, br. 1198.

${ }^{22}$ Vidjeti: El-Mevsuatul-fikhijjetul-kuvejtijje, 5/135.

${ }^{23}$ Buhari, br. 4199 i Muslim, br. 1940.

${ }^{24}$ Vidjeti: Ibnu Hazm, El-Muhalla, 6/79.
} 
škorpioni, puževi i drugi beskičmenjaci, a tu spadaju i insekti. Ovakva podjela nema utjecaja na status konzumiranja ovih životinja, ali ima utjecaj na pitanje njihove čistoće i nečistoće. Naime, kada ugine životinja koja ima krvotok, njena strvina je nečista, za razliku od strvine životinje koja nema krvotok. Hanefijski učenjaci smatraju da je sve ove životinje haram konzumirati, jer je to ogavno zdravoj ljudskoj prirodi. Nasuprot ovog mišljenja jeste stav malikija, koji smatraju da su sve ove vrste, ukoliko se zakolju na propisan način, dozvoljene ljudima kojima to ne šteti. Šafijski i hanbelijski učenjaci iz zabrane izuzimaju neke vrste koje liče dozvoljenim životinjama ili ih ne smatraju ogavnim. ${ }^{25}$

Iz zabrane insekata izuzimaju se skakavci, koji su dozvoljeni konsenzusom islamskih učenjaka. Abdullah b. Omer, radijallahu anhu, prenosi da je Allahov Poslanik, sallallahu alejhi ve sellem, rekao: "Dozvoljene su nam dvije vrste strvi i dvije vrste krvi. Što se tiče uginulih životinja, to su ribe i skakavci, a što se tiče krvi, to su jetra $\mathrm{i}$ slezena."26

Islamski pravnici su iz zabrane izuzeli i crve koji se pojave u nekoj hrani ako se pojedu zajedno s tom hranom, dok ih odvojeno nije dozvoljeno konzumirati. $^{27}$

Većina islamskih učenjaka iz zabrane je izuzela bodljorepog pustinjskog guštera (dabb) pozivajući se na predanje od Ibn Abbasa $u$ kojem se navodi da je pečen pustinjski gušter postavljen pred Allahovog Poslanika, sallallahu alejhi ve sellem, pa je pružio svoju ruku da počne jesti, ali je neko od prisutnih rekao: "Allahov Poslaniče! To je meso pustinjskog guštera”, pa je on povukao svoju ruku. Onda ga je Halid b. Velid, radijallahu anhu, upitao: "Allahov Poslaniče, je li on zabranjen?" On mu reče: "Nije, ali ga nije bilo u mojoj zemlji pa mi se gadi." Halid je potom pružio ruku i jeo guštera, a Allahov Poslanik, sallallahu alejhi ve sellem, ga je gledao. ${ }^{28}$ Ebu Hanifa smatra zabranjenim konzumiranje pustinjskog guštera, a u tome se pozvao na

25 Vidjeti: Kasani, Bedaius-sanai', 5/36, Hattab, Mevahibul-Dželil, 4/349, Dusuki, Hašijetud-Dusuki alaš-Šerhil-kebir, 2/115, Ensari, Esnal-metalib, 1/567, Ibnu Kudama, El-Mugni, 9/406, i El-Mevsuatul-fikhijjetul-kuvejtijje, 5/141.

${ }^{26}$ Ahmed, br. 5723, Ibnu Madža, br. 3314. Hadis je sahih po ocjeni Albanija.

${ }^{27}$ Vidjeti: El-Mevsuatul-fikhijjetul-kuvejtijje, 5/143.

${ }^{28}$ Buhari, br. 5391 i Muslim, br. 1945. 
predanje Abdurrahmana b. Hasene, radijallahu anhu, koji kazuje kako su bili u vojnom pohodu s Allahovim Poslanikom, sallallahu alejhi ve sellem, pa ih je snašla velika glad, te su neki ashabi ulovili bodljorepe pustinjske guštere i kuhali ih. Kada je o tome saznao Allahov Poslanik, sallallahu alejhi ve sellem, naredio je da se prospu. ${ }^{29}$ Oni koji zastupaju prethodno mišljenje ovo predanje tretiraju derogiranim, a neki su učenjaci uskladili između tih predanja kazavši da je meso ovog guštera pokuđeno. $^{30}$

\section{Životinje koje nastaju ukrštanjem dozvoljene $i$ zabranjene životinje}

Životinje koje nastaju ukrštanjem dozvoljene i zabranjene životinje, kao što je mazga, zabranjeno je konzumirati, jer se tu objedinio halal i haram te se iz predostrožnosti preferira zabrana. Ovo je stav šafijskih i hanbelijskih učenjaka, dok hanefijski i malikijski učenjaci smatraju da ukrštena životinja ima status svoje majke, bila ona dozvoljena ili zabranjena, s tim što malikijski učenjaci uvjetuju da tako rođena životinja, da bi se smatrala dozvoljenom, mora da nalikuje na majku, a ako bi nalikovala na oca, tada bi bila zabranjena, iako joj je majka dozvoljena. ${ }^{31}$

\section{Životinje koje ne žive $u$ arapskim predjelima}

To su životinje koje nisu poznavali Arapi na čijem je jeziku objavljen Kur'an. One se dijele na tri skupine: Prva su životinje koje nalikuju životinjama čije su meso Arapi smatrali lijepim, i one su halal. Druga vrsta jesu životinje koje nalikuju životinjama čije su meso Arapi smatrali ogavnim, i one su haram. Na to ukazuje kur'anski ajet: "Pitaju te što im se dozvoljava. Reci: 'Dozvoljavaju vam se lijepa jela...'” (ElMaida, 4), tj. dozvoljava vam se ono što vi - Arapi vidite lijepim, jer oni su o tome pitali i njima je usmjeren odgovor. U drugom ajetu Uzvišeni Allah kaže: "Koji će im lijepa jela dozvoliti, a ružna im

\footnotetext{
${ }^{29}$ Ahmed, br. 17759, hadis je sahih po ocjeni Šuajb Arnauta.

${ }^{30}$ Vidjeti: Kasani, Bedaius-sanai', 5/36, El-Mevsuatul-fikhijjetul-kuvejtijje, 5/142.

${ }^{31}$ Vidjeti: Kasani, Bedaius-sanai', 5/37, Dusuki, Hašijetud-Dusuki alaš-Šerhil-kebir, 2/117, Remli, Nihajetul-muhtadži ila šerhil-minhadž, 8/144, Ibnu Kudama, El-Mugni, 9/407, El-Mevsuatul-fikhijjetul-kuvejtijje, 5/142.
} 
zabraniti" (El-A'raf, 157). Dakle, ono što Arapi vide lijepim, to je halal, a ono što vide ružnim i ogavnim, to je haram. Ovo se odnosi na stanovnike naseljenih mjesta Hidžaza, jer Kur'an je objavljen na njihovom jeziku i njima se prvo obratio. Stanovnici pustinje u ovom pitanju nisu mjerodavni, jer oni, zbog nestašice, jedu šta nađu.

Treća skupina jesu životinje koje ne nalikuju ni životinjama koje su smatrali lijepim, niti onima koje su smatrali ružnim. Takve životinje su dozvoljene na osnovu pravila o općoj dozvoli svega što vjerom nije zabranjeno. Ovo je stav učenjaka hanefijskog mezheba, a blizak mu je i stav šafijskih i hanbelijskih učenjaka. S druge strane, malikijski učenjaci ne osvrću se na procjenu Arapa Hidžaza, da li je nešto lijepo ili ne, nego vide dozvoljenim sve što šerijatskim tekstom nije zabranjeno pozivajući se na opće pravilo o dozvoli. ${ }^{32}$

Postoje i vanredni uzroci zabrane mesa nekih životinja koje su inače dozvoljene. Primjer za to jeste divljač koju ulovi muhrim - osoba koja obavlja obrede hadža ili umre, kao i divljač koja se ulovi unutar Harema, zaštićene zone u Meki, a prema mišljenju nekih učenjaka i u Medini. ${ }^{33}$

\section{Životinje koje se hrane nečistom hranom}

Meso životinje koja je inače dozvoljena može postati zabranjeno, odnosno pokuđeno, zbog hrane kojom se hrani. Životinja koja se pretežno hrani nečistoćom naziva se džellala. Hanefijski i hanbelijski učenjaci smatraju da je zabranjeno jesti meso i piti mlijeko životinje čija je dominantna hrana nečistoća. Šafijski učenjaci smatraju da su meso, mlijeko i jaja džellale pokuđeni, ali da nisu zabranjeni, dok su malikije stanovišta da je to dozvoljeno. Argument koji ukazuje na zabranu jeste predanje Ibn Omera, radijallahu anhu, u kojem kaže: "Allahov Poslanik, sallallahu alejhi ve sellem, zabranio je jedenje mesa i pijenje mlijeka džellale (životinje koja najviše jede nečist)." 34

\footnotetext{
32 Vidjeti: Ibnu Abidin, Hašijetu Ibnu Abidin, 6/305 i El-Mevsuatul-fikhijjetulkuvejtijje, 5/146.

${ }^{33}$ El-Mevsuatul-fikhijjetul-kuvejtijje, 5/147.

${ }^{34}$ Ebu Davud, br. 3787, Tirmizi, br. 1824 i drugi. Tirmizi kaže da je hadis hasen-garib, a jakim ga je ocijenio Ibnu Hadžer. Vidjeti: Et-Telhis, 4/384.
} 
Oni koji zastupaju drugo mišljenje shvatili su da ovo predanje ukazuje na pokuđenost, a ne na strogu zabranu. Protagonisti trećeg mišljenja kažu da meso džellale, iako je nastalo od nečisti, nije nečisto jer se nečist transformirala u drugu materiju. Odabrano je drugo mišljenje, prema kojem je meso džellale pokuđeno, osim ako bi njeno meso poprimilo miris nečisti, i onda bi bilo zabranjeno, jer je trag nečisti evidentan. Isto tako, zabranjeno je ako bi se ispostavilo da šteti ljudskom zdravlju. Sve ovo ne odnosi se na životinje koje samo ponekad jedu nečistu hranu, nego na životinje koje se najviše hrane nečistoćom. Pokuđenost konzumiranja mesa džellale anulira se na način da se životinja prestane hraniti nečistoćom i da se hrani čistom hranom neko vrijeme, tako da se pročisti od nečistoće. ${ }^{35}$

\section{Krv zaklane životinje $i$ životinjski proizvodi}

Krv životinje koja istekne prilikom klanja haram je konzumirati, prema konsenzusu islamskih učenjaka, dok je dozvoljena krv koja preostane $\mathrm{u}$ venama, mesu, srcu i sl. ${ }^{36}$

Životinjski proizvodi, kao što su mlijeko i jaja, u šerijatskom tretmanu prate životinju od koje potječu. Tako, naprimjer, dozvoljeno je mlijeko životinje čije je meso dozvoljeno konzumirati, dok je zabranjeno mlijeko zabranjene životinje. ${ }^{37}$

\section{Uvjeti koji se moraju ispuniti da bi klanje životinja bilo u skladu s islamskim normama}

Kada se radi o životinjama čije je prirodno stanište voda, one su dozvoljene i bez klanja. Kopnene životinje, čije je meso dozvoljeno konzumirati, dijele se na divlje i domaće. Kada je riječ o divljim životinjama i uvjetima da bi meso ulovljene životinje bilo halal, to je posebna tema na koju se ovom prilikom nećemo osvrtati. Da bi meso pitome životinje bilo halal, potrebno je da se životinja zakolje na

35 Serahsi, El-Mebsut, 11/217, Kasani, Bedaius-sanai', 5/40, Hattab, MevahibulDželil, 1/94, 4/347, Nevevi, El-Medžmu', 9/28, Ibnu Kudama, El-Mugni, 9/413.

${ }^{36}$ Vidjeti: Karafi, Zehire, 1/185.

37 Vidjeti: Kasani, Bedaius-sanai', 5/43, Hiraši, Šerhu Muhtesari Halil, 1/85, Remli, Nihajetul-muhtadži, 1/226-227, Ruhejbani, Metalibu ulinnuha,1/233-234 i ElMevsuatul-fikhijjetul-kuvejtijje, 5/153-155. 
propisan način, naravno ako se radi o životinji koja nije sama po sebi zabranjena, kao što je svinja ili pas. Ako bi životinja sama uginula ili bila ubijena na neki drugi način, mimo propisanog klanja, njeno meso tretira se strvinom i zabranjeno ga je jesti. Svevišnji Allah kaže: “Zabranjuje vam se strv, i krv, i svinjsko meso, i ono što je zaklano u nečije drugo, a ne u Allahovo ime, i što je udavljeno i ubijeno; i što je strmoglavljeno, i rogom ubodeno, ili od zvijeri načeto - osim ako ste ga preklali - i što je na žrtvenicima žrtvovano..." (El-Maida, 3). Allahov Poslanik, sallallahu alejhi ve sellem, govorio je: "Jedite meso životinja kojima je puštena krv i nad kojima je pritom spomenuto Allahovo ime." 38 Puštanjem krvi meso životinje se čisti, a spominjanjem Allahovog imena, zahvaljujemo se Allahu i priznajemo Njegove blagodati kad nam je tu stoku potčinio.

Da bi klanje bilo validno, potrebno je da se ispune određeni uvjeti od kojih se neki tiču životinje koja se kolje, neki onog ko kolje, a neki pribora i načina klanja. Što se životinje tiče, uvjetuje se da bude živa u trenutku klanja, da klanje bude izravni uzrok njene smrti i, naravno, da životinja bude dozvoljena.

Uvjetuje se da osoba koja kolje bude musliman, ili ehlul-kitabija (sljedbenik Knjige), odnosno jevrej ili kršćanin, dok meso životinja koje zakolju drugi nemuslimani nije dozvoljeno. Tako, naprimjer, meso životinje koju zakolje ateist ili budist nije dozvoljeno. Također se uvjetuje da onaj ko kolje bude razuman tako da shvata značenje klanja i Bismille. Većina učenjaka, tj. hanefije, malikije i hanbelije, uvjetuju da osoba koja kolje prilikom klanja spomene Allahovo ime, odnosno da izgovori: "Bismillah! - U ime Allaha!", namjeravajući da klanje bude u ime Allaha. Ako osoba koja kolje, iz zaborava ne spomene Allahovo ime, meso životinje je halal, ali ako bi namjerno izostavila Bismillu, meso tako zaklane životinje bilo bi haram. Učenjaci šafijske pravne škole smatraju da je izgovaranje Bismille prilikom klanja pohvalno, ali da nije uvjet za klanje. Ako bi osoba koja kolje žrtvovala životinju u nečije drugo ime mimo Allaha, tako da prilikom klanja spominje i veliča nekog drugog mimo Allaha, meso te životinje bilo bi haram. Ako je osoba koja kolje jevrej ili kršćanin, uvjetuje se da ne znamo da je prilikom klanja spomenula nečije drugo ime mimo Allaha veličajući ga,

${ }^{38}$ Buhari, br. 2488 i Muslim, br. 1968. 
a ako čujemo da je prilikom klanja spomenula, naprimjer, Isusa, tada je meso zaklane životinje haram. U ranije citiranom ajetu, u kojem se spominju načini na koje meso životinje, ako ona ugine, postaje haram, navodi se: "...i ono što je zaklano u nečije drugo, a ne u Allahovo ime..." (El-Maida, 3)

Također se uvjetuje da se životinja zakolje u predjelu vrata, a alatka za klanje mora biti oštra i ne smije se dizati sa životinje dok se čin klanja ne okonča, a što znači dok se ne presiječe dušnik, jednjak, te glavne arterije i vene vratne regije. Presijecanjem dušnika, jednjaka i obje arterije ostvaruje se klanje na najpotpuniji način, a ako se nešto od toga ne bi presjeklo, validnost klanja je predmet rasprava među učenjacima. Ebu Hanifa, rahimehullah, uvjetuje da se presiječe većina, a to su bilo koje tri od četiri vratne žile. Ovo je opis klanja domaćih životinja izuzev deva, koje se kolju ubodom u podnožju vrata (nahr), gdje se spajaju ključne kosti. Pri tome se presijeku krvne žile, a, prema malikijama, dovoljno je da se deva ubode na tom mjestu i tako usmrti. ${ }^{39}$

Ovi su uvjeti neophodni da bi klanje uopće bilo validno, a pored toga u islamu postoji i niz pohvalnih radnji kojih se lijepo pridržavati prilikom klanja, a cilj im je blagost i samilost prema životinji. Primjer za to jeste da se nož ne oštri pred očima životinje koja će se klati, da se životinja ne kolje dok druga to gleda, da se ne kolje tupim nožem, da se životinja ne muči, da se ne počinje s odstranjivanjem kože životinje, odsijecanjem njenih dijelova, barenjem u vrućoj vodi ili perutanjem sve dok se ne potvrdi da je životinja umrla.

\section{Načini klanja u savremenim klaonicama}

Nakon što smo opisali klanje životinja prema islamskim normama, ostaje da se vidi kako se to obično dešava u današnjim klaonicama.

U savremenim klaonicama životinje se usmrćuju raznim metodama od kojih su najčešće sljedeće:

Prva - Strujni udar: Životinja se izloži strujnom udaru, koji je ošamuti ili usmrti.

${ }^{39}$ Vidjeti: Kasani, Bedaius-sanai', 5/41-42 Savi, Belegatus-salik li akrebil-mesalik, 2/154-158 i El-Mevsuatul-fikhijjetul-kuvejtijje, 21/178-199. 
Druga - Gušenje ugljendioksidom: Ovaj način obično se koristi za ubijanje sitnih životinja u velikom broju, kao što su pilići, tako da se u posebne komore u koje su smještene životinje pusti plin ugljendioksid usljed čega nastupa smrt gušenjem.

Treća - Udarac u glavu: To je metoda koja se bazira na udaranju životinje u glavu čekićem, pištoljem i sličnim priborom, usljed čega životinja gubi svijest ili umire.

Četvrta - Ubrizgavanje zraka u grudni koš životinje, tako da se između rebara probije opna grudnog koša i kroz taj otvor ubrizgava se zrak te usljed pritiska na plućima nastaje smrt gušenjem, bez prolijevanja krvi. $^{40}$

Životinja koja bude ubijena na jedan od spomenutih načina smatra se strvinom i njeno meso je haram, jer nije zaklana na propisan način.

Nekada se ove ili neke druge metode koriste da se životinja samo ošamuti, a potom se kolje ili ubija. Međunarodno vijeće islamskog prava nastalo iz Organizacije islamske konferencije analiziralo je aktuelne metode klanja životinja u zemljama iz kojih muslimanske zemlje uvoze meso, te su, između ostalog, u svom zaključku naveli da se prilikom šerijatskog klanja u osnovi ne koristi ošamućivanje životinje, jer kada se ispune uvjeti i običaji klanja kako to islam nalaže, to je najpotpuniji i najljepši način klanja pri kojem se blago i pažljivo postupa prema životinji i tako se najmanje pati. Ako se životinja samo ošamuti nekom od spomenutih metoda, a potom, dok je još uvijek živa, zakolje na propisan način, njeno je meso halal, ali se pri tome uvjetuje da se ispune tehnički uvjeti putem kojih se potvrđuje da životinja nije umrla prije klanja. Međunarodno vijeće islamskog prava ističe da nije dozvoljeno kao metod za ošamućivanje životinje prije klanja upotrijebiti pištolj s probojnom iglom, niti je dozvoljeno to činiti udaranjem životinje čekićem ili maljom, niti ubrizgavanjem zraka u grudni koš. Također ističu da nije dozvoljeno da se kokoši ošamućuju strujnim udarom, jer se praktično pokazalo da to rezultira smrću nemalog broja njih.

\footnotetext{
${ }^{40}$ Vidjeti: Hatamile Samir, Ahkamu zebaih gajril-muslimin vel-luhumil-mustevredeti minhum, str. 424-425.
} 
U velikim tvornicama za preradu peradi za klanje se često koristi automatski nož za odsijecanje glava. Pilići se glavom prema dolje vješaju za noge na pokretnoj traci koja ih navodi na nož koji im siječe glave. Međunarodno vijeće islamskog prava konstatira da se u pravilu kokoši, kao i druge životinje, kolju rukom čovjeka, ali ne smeta i da se upotrijebi automatski nož prilikom klanja kokoši, sve dok su opći uvjeti klanja ispunjeni. A što se tiče izgovora Bismille, dovoljno je da se jedanput kaže "bismillah" za cjelokupnu seriju koja se uzastopno kolje, a kada se klanje prekine, za novu seriju ponovo će se izgovoriti "bismillah". 41

\section{(Ne)dozvoljenost jedenja mesa iz zemalja čije većinsko stanovništvo čine ehlul-kitabije}

Ukoliko bi se uvjeti klanja koje je islam definirao ispunjavali $\mathrm{u}$ klaonicama zemalja čije većinsko stanovništvo čine ehlul-kitabije, odnosno kršćani i jevreji, to meso bilo bi halal, na osnovu kur'anskog ajeta: "I dozvoljavaju vam se jela onih kojima je data Knjiga" (ElMaida, 5).

Međutim, mnoga istraživanja pokazuju da se u tim klaonicama životinje ubijaju na islamom neprihvatljiv način. Štaviše, u nekim zemljama na snazi je zakon kojim se zabranjuje da se životinje kolju presijecanjem vratnih žila. Takav način klanja tretiraju nehumanim i uvjetuju da se životinje ubijaju nekom od metoda koje smatraju da su blaže i lakše za životinje. ${ }^{42}$

Meso porijeklom iz zemalja čije većinsko stanovništvo čine ehlulkitabije može se klasificirati u tri kategorije: prva je meso životinja za koje se zna da su zaklane po propisima Šerijata i takvo je meso, bez sumnje, halal; druga kategorija je meso životinja za koje se zna da nisu zaklane po propisima Šerijata i takvo je meso, bez sumnje, haram; i treća kategorija je meso životinja za koje se ne zna kako su zaklane.

\footnotetext{
${ }^{41}$ Vidjeti: Zaključak Međunarodnog vijeće islamskog prava nastalog iz Organizacije islamske konferencije, br. 95, Kararatun ve tevsijatun Medžmeil-fikhil-islamijidduveli, sabrao: Abdulhakk el-Ajfe, 191-193.

${ }^{42}$ Vidjeti: dr. Fevzan Salih b. Fevzan, El-Atimetu ve ahkamus-sajdi vez-zebaih, str. 150, dr. Hatamile Samir, Ahkamu zebaih gajril-muslimin vel-luhumil-mustevredeti minhum, str. 430-431.
} 
Neki savremeni učenjaci smatraju ovu kategoriju dozvoljenom pozivajući se na opće značenje kur'anskog ajeta: "I dozvoljavaju vam se jela onih kojima je data Knjiga" (El-Maida, 5), što znači da je u pravilu meso koje kolju ehlul-kitabije dozvoljeno sve dok ne budemo znali da je životinja zaklana na nepropisan način. Druga skupina savremenih učenjaka smatra da je ovakvo meso haram, jer je u pravilu svako meso zabranjeno sve dok se ne potvrdi da je životinja propisno zaklana, a to je u ovom slučaju vrlo neizvjesno te stoga takvo meso ostaje zabranjeno. Ovo mišljenje je odabrano, jer načini na koje se životinje tretiraju u tim zemljama, kao što je već ranije spomenuto, jasno govore da se ubijaju na način koji ih čini strvinom. To je postalo naročito jasno nakon 2013. godine, kada su u zemljama Evropske unije stupili na snagu novi zakoni koji čine klanje na islamski način gotovo nemogućim. ${ }^{43}$ Svemu prethodnom, može se dodati i činjenica da se nemali broj stanovnika ovih zemalja deklariraju kao ateisti, deisti ili agnostici, što znači da se zbog toga ne mogu smatrati ehlul-kitabijama, a to opet povećava sumnje da osoba koja kolje ne ispunjava potrebne uvjete. Stoga se musliman u ovim zemljama ograničava samo na meso pouzdanih proizvođača, koji vode računa o halalu. Natpis halal na mesnim proizvodima često je obična reklama bez ikakvog stvarnog značenja. Prihvatljiv je samo onaj natpis iza kojeg stoji ozbiljna institucija, koja prati i nadzire proces klanja i vodi računa da šerijatski uvjeti budu ispunjeni.

\section{Zaključak}

Prema odabranom mišljenju islamskih pravnika, ribe je dozvoljeno konzumirati bez obzira kako uginule izuzev ako bi se njihovo meso pokvarilo, u tom slučaju zabranjeno je zbog štetnosti, a sve životinje koje žive isključivo u vodi u pravilu su dozvoljene.

Krave, deve, ovce i koze dozvoljene su konsenzusom islamskih učenjaka. Meso divljih životinja koje nisu mesojedi i ne spadaju u gmizavce i glodare, kao što su srne i zebre, dozvoljeno je konsenzusom islamskih učenjaka.

\footnotetext{
43 Vidjeti: Dr. Hatamile Samir, Ahkamu zebaih gajril-muslimin vel-luhumilmustevredeti minhum, str. 423-424.
} 
Ptice koje nisu grabljivice niti lešinari, kao što su kokoši, patke, golubovi i sl., dozvoljeno je konzumirati. Iz dozvole se izuzimaju životinje koje je Zakonodavac naredio da se ubijaju ili je zabranio da se ubijaju i one koje su ogavne ljudima zdrave prirode. Zečevi su također dozvoljeni prema većini islamskih učenjaka. Odabrano je mišljenje da je konjsko meso dozvoljeno ili pokuđeno, ali nije zabranjeno jesti.

Neupitnim konsenzusom zabranjena je samo jedna životinja, to je svinja, dok u pogledu ostalih zabranjenih životinja postoje veća ili manja razilaženja.

Prema odabranom mišljenju koje zastupa većina islamskih učenjaka zabranjeno je meso zvijeri, mesojeda, a prema oficijelnom stavu malikijskih učenjaka meso ovih životinja je pokuđeno, ali nije strogo zabranjeno.

Ptice grabljivice, kao što su jastreb i orao, te ptice koje se pretežno hrane strvinom, kao što su lešinari i neke vrste gavranova, zabranjeno je jesti, prema odabranom mišljenju koje zastupa većina islamskih učenjaka, nasuprot zvaničnom stavu malikija.

Meso magaraca zabranjeno je prema mišljenju većine islamskih učenjaka.

Gmizavce, glodare i insekte haram je konzumirati prema učenjacima hanefijskog mezheba. Malikije su stanovišta da su ove vrste, ukoliko se zakolju na propisan način, dozvoljene ljudima kojima to ne šteti. Šafijski i hanbelijski učenjaci iz zabrane izuzimaju neke vrste koje liče dozvoljenim životinjama ili ih ne smatraju ogavnim.

Iz zabrane insekata izuzimaju se skakavci, koji su dozvoljeni konsenzusom islamskih učenjaka. Iz zabrane se izuzimaju i crvi koji se pojave u nekoj hrani ako se pojedu zajedno s tom hranom, dok ih samostalno nije dozvoljeno konzumirati. Većina islamskih učenjaka iz zabrane je izuzela bodljorepog pustinjskog guštera (dabb).

Životinje koje nastaju ukrštanjem dozvoljene i zabranjene životinje, kao što je mazga, zabranjeno je konzumirati, prema odabranom mišljenju.

Meso životinje koja je inače dozvoljena može postati zabranjeno, odnosno pokuđeno, ako se hrani nečistom hranom. 
Meso porijeklom iz zemalja čije većinsko stanovništvo čine ehlulkitabije može se klasificirati u tri kategorije: prva je meso životinja za koje se zna da su zaklane po propisima Šerijata, i takvo je meso halal; druga kategorija je meso životinja za koje se zna da nisu zaklane po propisima Šerijata, i takvo je meso haram; i treća kategorija je meso životinja za koje se ne zna kako su zaklane. Neki savremeni učenjaci smatraju ovu kategoriju dozvoljenom, a odabrano je mišljenje da je takvo meso haram.

\section{Literatura:}

1. Ahmed b. Hanbel eš-Šejbani, El-Musned, Muessesetu Kurtuba, Kairo.

2. Badži, Sulejman b. Halef, El-Munteka šerhul-Muvetta, Darul-Kitabilislami, El-Kahire, drugo izdanje.

3. Buhari, Muhammed b. Ismail, Sahihul-Buhari (Buharijeva zbirka hadisa), Daruššsuab, Kairo, 1987. g.

4. Dusuki, Muhammed b. Ahmed, Hašijetud-Dusuki alaš-Šerhil-kebir, Darul-fikr.

5. Ebu Davud, Sulejman b. El-Eš'as es-Sidžistani, Sunenu Ebi Davud, Darul-fikr, Bejrut.

6. El-Mevsuatul-fikhijjetul-kuvejtijje, Vizaretul-evkafi veš-šu'unilislamijje, Kuvajt, Darus-selasil, 1427. h. g.

7. Ensari, Zekerija b. Muhammed, Esnal-metalib fi šerhi Revdit-talib, Darul-kitabil-islami.

8. Fevzan, dr. Salih b. Fevzan el-Fevzan, El-Atimetu ve ahkamus-sajdi vez-zebaih, Mektebetul-mearif, Rijad, prvo izdanje, 1988. g.

9. Hatamile, Samir Abdulhadi Mahmud, Ahkamu zebaih gajril-muslimin vel-luhumil-mustevredeti minhum, Sakarya Universitesi, El-Hejetul'alemijjetu lil-iktisadi vet-temvilil-islami.

10. Hattab, Šemsud-din Ebu Abdullah Muhammed b. Muhammed, Mevahibul-Dželil lišerhi muhtesari Halil, Daru 'alemil-kutub, Rijad, 1423. h. g.

11. Hiraši, Muhammed b. Abdullah, Šerhu Muhtesari Halil, 1/85,

12. Ibnu Abidin, Muhammed b. Omer, Hašijetu Ibnu Abidin, Darul-fikri, Bejrut, drugo izdanje, 1992.

13. Ibnu Hadžer, Ahmed b. Alij Ebu Fadl el-Askalani, Telhisul-habiri fi tahridžil-ehadisir-rafi'il-kebir, darul-kutubil-ilmijje, prvo izdanje, 1419. h. g. 
14. Ibnu Hazm, Ebu Muhammed Ali b. Ahmed b. Seid el-Endelusi, ezZahiri, El-Muhalla šerhul-Mudžella, Darul-fikri, Bejrut.

15. Ibnu Kudame, Abdullah b. Ahmed el-Makdisi, El-Mugni, MektebetulKahire, 1968.

16. Ibnu Madža, Muhammed b. Jezid el-Kazuvejni, Sunenu Ibnu Madža, Mektebetu Ebil-Me'ati.

17. Ibnu Rušd, Ebul-Velid Muhammed b. Ahmed, El-Bejanu vet-tahsil, Darul-Garbil-islami, Bejrut, drugo izdanje, 1988.

18. Ibrahim Mustafa, El-Mu'džemul-vesit, El-Mektebetul-islamijjetu, Darud-daveti, valorizacija: medžmeul-lugatil-arabijje.

19. Kanurić Hakija, Aditivi i emulgatori u hrani i piću, Zbornik radova br. 10, IPF u Bihaću, 2018. g.

20. Karafi Šihabuddin b. Idris, Zehire, Darul-garbil-islami, Bejrut, 1994.

21. Kararatun ve tevsijatun Medžmeil-fikhil-islamijid-duveli, sabrao: Abdulhakk el-Ajfe.

22. Kasani, Alauddin b. Mesud, Bedaius-sanai' fi tertibiš-šerai', Darulkutubil-ilmijje, drugo izdanje, 1986.

23. Merginani, Ebul-Hasan Ali b. Ebi Bekr Abdul-Dželil, El-Hidaje šerhul-Bidaje, El-Mektebetul-islamijje.

24. Muslim bin el-Hadždžadž en-Nejsaburi, Sahihu Muslim (Muslimova zbirka hadisa), Daru ihjait-turasil-arabi, Bejrut.

25. Nevevi, Ebu Zekerijja Muhjud-din Jahja b. Šeref, El-Medžmu' šerhulMuhezzeb liš-Širazi, Darul-fikr.

26. Remli, Šemsuddin b. Ebi Abbas, Nihajetul-muhtadži ila šerhilminhadž, Darul-fikr, Bejrut, 1984.

27. Ruhejbani, Mustafa b. Sad, Metalibu ulinnuha fi šerhi Gajetilmuntaha, El-Mektebul-islami, 1994.

28. Savi, Ahmed b. Muhammed, Belegatus-salik li akrebil-mesalik, Darulmearif.

29. Serahsi, Šemsud-din Ebu Bekr Muhammed b. Ebu Sehl, El-Mebsut, valorizacija: Halil Muhjud-din el-Mejs, Darul-fikr, Bejrut, prvo izdanje, 1421. h. g.

30. Tirmizi, Muhammed b. 'Isa Ebu 'Isa, El-Džamius-sahih - sunenutTirmizi, Daru ihjait-turasil-'arabi, Bejrut. 


\title{
HALAL MEAT AND MODERN WAYS OF ANIMAL SLAUGHTER
}

\author{
PhD Hakija Kanurić, Islamic Faculty of Pedagogy \\ University of Bihać
}

E-mail: hakijak@hotmail.com

Summary

The meat of some animals is absolutely forbidden to consume while the meat of others is allowed under certain conditions. Animals that live solely in water are allowed without slaughter, except for land animals whose meat will only be allowed if they are slaughtered in a special way. Due to that it is necessary to fulfill certain conditions related to the animal itself, the person who is slaughtering, the way it has been done and the accessories it uses. This paper deals with the analysis of these conditions, with an overview of the ways of killing animals in modern slaughterhouses. By comparing the four known mezheb, the views of scholars about the types of animals whose meat is forbidden to be eaten are explicated. Also it highlights the issues in which scholars have taken a unique position and the issues in which they have diverged, as well as the arguments they invoke and which opinion is preferred. Keywords: Islam, food, meat, animals, slaughterhouses, halal, haram. 


$$
\begin{gathered}
\text { الدكتور المحاضر هاكيا كانوريتش } \\
\text { كلية التربية الإسلامية }
\end{gathered}
$$

E-mail:hakijak@hotmail.com

\section{اللحم الحلال وطرق الذبح في المسالخ المعاصرة}

\section{الملخص | (الخص}

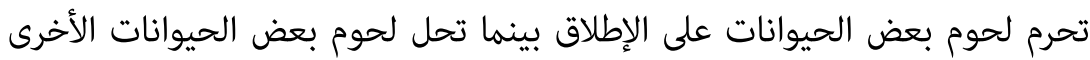

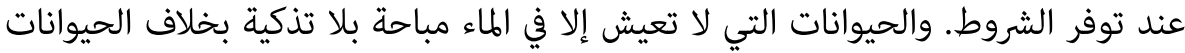

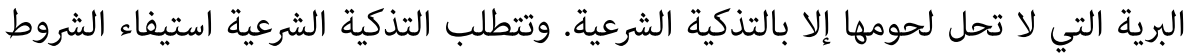

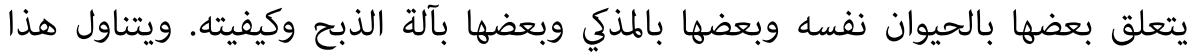

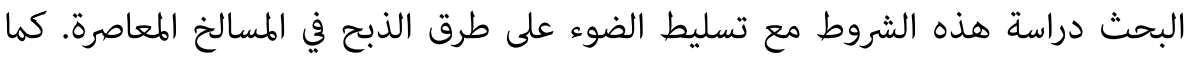

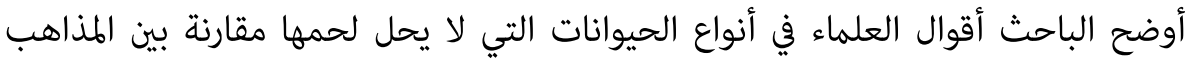

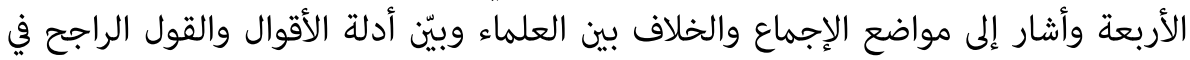

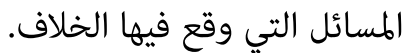
الكلمات المفتاحية: الإسلام، الطعام، اللحم، الحيوانات، الحلان، الحلات، الحرام. 